\title{
THE STRATEGIC MANAGEMENT IN TERMS OF AN ENTERPRISE'S TECHNOLOGICAL DEVELOPMENT
}

\author{
- Alla S. Ivanova, Nataliia G. Holionko, Tetiana B. Tverdushka, Tadeusz. \\ Olejarz, Alina Y. Yakymchuk
}

\begin{abstract}
The objective of this research was to focus on a new approach to consequence assessment of a company's technological development. In view of the impact of a company's technical and technological development regime on the efficiency of its operation, we used the method of assessing the core business along with pairwise comparisons to assess the basic business potential of a single company and related groups. Our proposed method for evaluating the business core was based on the technique of pairwise comparisons using the work of T. Saaty along with Fishburn's method. We analyzed the hierarchical structure of the chosen enterprises using the following metrics: products, consumers, intangible assets, distribution channels and capital. In order to identify the technological basis of the enterprise's competitive advantages, we first initiated a decomposition of the enterprise's technological structure: business core, periphery and prospects. We used data obtained from the machine-tool sector of Ukraine, a country which demonstrates how a lack of effective technological development along with inadequate tools for the development and implementation of technological strategies can lead to significant destructive effects on national competitiveness. In particular, we pointed to a decrease in rates of return and profitability of production. In conclusion, we argue that a passive management policy of an enterprise with regard to its technological development can lead to catastrophic consequences for competitiveness in terms of innovation and development.
\end{abstract}

Keywords: management, technological development; competitiveness, business core concept; technological development strategy, strategic management model of enterprise's technological development

JEL Classification: 014

Received: July, 2019

1st Revision: October, 2019

Accepted: October, 2019

\section{INTRODUCTION}

The characteristic feature of an enterprise's activity and development in the modern innovative economy is the formation of a stable competitive advantage on the basis of its ability to continue to modernize its technology. Technological development and innovation have become the main engine of economic growth of modern society. Innovations cover all areas of business as well as 
orient the enterprise toward continually seek new technologies in all aspects of its business: production, information, management and marketing. Specialized technological knowledge plays the leading role in ensuring revenue and the profitability of the enterprise. Companies that can manage a sufficient amount of R \& D investment and use the results to create new products, services and technologies will secure more greatly significant benefits in innovation and technology advancement than their competitors. Consequently, the factors of monitoring, forecasting impact, and developing measures to regulate the technological upgrade of the enterprise become vital urgent, especially for countries with economies in transition, i.e. nations in which enterprises have not in the past devoted particular attention to the strategic issues of their technological development.

The purpose of our study is to highlight the strategic directions of the development of machinebuilding technologies and their impact on the technological development of the machine-tool industry in general. In addition, the internal and external tools for analyzing the technological environment of an enterprise will be defined. We applied our own approach to assessing the core business and predicting the impact on the machine-tool industry, i.e. the technique of studying pairwise comparisons of Saati (1977) to predict the values of indicators regarding core business development. Thus, in order to provide a comprehensive analysis and development of the technological potential of the company, we propose to take into account not only quantitative indicators, as is usually done in many modern studies, but also qualitative components. We believe that regarding the formation of the competitiveness of an enterprise, it is important to consider the development of programs for technological development; here, we analyze the availability of substitute technologies within the framework of the model "5 forces of competition" of Porter. Investigating the assessment of trends and forecasts in terms of the consequences of developing a technology development strategy, we based our study theoretically on the established preconditions and consequences of the technological development of enterprises, including innovative technologies, with results summarized in a literature review. The next section of the present article, Data and Methods, describes our research methodology, discusses the indicators for forecasting and the methodology used regarding their definition. The following section, Results, focuses on a brief discussion of the ratings themselves. Finally, we state our conclusions based on the analysis of hierarchy process as defined in this study.

\section{THEORETICAL BACKGROUND}

The term "technology" is obviously quite commonly used in the field of management, however this concept can be interpreted in several ways. Most definitions interpret technology as a way of influencing a primary substance (matter, energy, information, or an aggregate of productive resources), resulting in the recognition of a receipt of the desired product or service. Other authors define technology as a set of technical operations, organizational procedures, rules, techniques, methods, along with the forms of their use, all of which is somehow structured to provide a predetermined result. The result of technology usually comes in the form of the products and services which comprise the intermediate and the end products of the organization.

The basic components of technology have been defined as a set of specialized knowledge, processes, materials and equipment. The elemental analysis of technology as a complex formation allows the observer to distinguish individual objects that determine both the current state of the 
enterprise and more or less generally predict and shape future changes to come. The important step of understanding the economic essence of technology is its recognition as a commodity that has its own consumer value and thus acquires a corresponding price in the buying and selling process (Schumpeter, 2011).

The modern interpretation of economic science technology takes the form of a set of production processes, scientific, technical and professional knowledge, methods, means of production, and new technologies which ensure the transformation of natural substances into industrial production toward commercial and domestic usage. The set of operations, rules and procedures that make up technology should be structured in a way to achieve a specific goal. The result of the technology usage is usually the intermediate and final versions of the enterprise's products and services. In a broader sense, technology is defined as the flow of specialized knowledge, processes and materials that are used in the design, production and operation of products (Bazhal et al., 2011; Schumpeter, 2011; Zemlickienè, et al., 2017).

The technological development of enterprises as a separate subject of research has attracted the attention of practitioners who investigate relevant issues regarding national or international analytical generalizations. At the same time, the intensification of innovation development and the formation of a new economy based on technologies leads to the intensification of not only applied but also scientific research into the causes and consequences of changing the key technologies in a society, i.e. influencing the spread of technological know-how as well as the dynamics of consumer behavior (Allen \& Zook, 2001; Szilágyi, 2017).

Consequently, research by Tsai \& Wang $(2008,2009)$ on the reasons for an enterprise's technological development has determined connections with the evolution of the technology itself. The researchers have demonstrated the current need to replenish the tools of strategic analysis of the technological environment with the goal of choosing promising new technologies to create or increase the competitive advantages of the enterprise. A decomposition of the technological structure of the enterprise using the method proposed in the Tsai \& Wang study is perceived by us as a useful methodological element that in some ways complements the methodology of the core concept of the business.

Strategic Management Consultants Allen \& Zook (2001), the creators of the kernel business concept have identified it as the methodological basis for the formation of a sustainable development strategy. In their work, the authors proceed from the idea that the basis of an enterprise's sustainable development is ensuring the company's integrity and using the core business concept to maximally effectivity, a strategy which will direct the operation towards long-term financial and market success.

Prahalad \& Hamel (1990) have noted how the foundation of such success can reside in the key competences of the company, i.e. the combinations and recombinations thereof. Such an approach allows the company to continuously create new products and to seize new markets, ensuring sustainable development (Bilan et al., 2017; Del Prado F. L. \& Rosellon M. A., 2017; Lim, 2016; Byun et al., 2018; Kačerauskas, 2015; Suder \& Kahraman, 2016;). Other authors (Draskovic et al., 2017; Krayneva et al., 2017; Werther et al., 1994) have indicated the knowledge component as the basis of a company's competitive position. The common view of many researchers is that 
modern approaches to managing company development should consider important intangible components, i.e. technologies, knowledge, capabilities and other intangible resources of the company. Therefore, we believe that the current target of strategic management of an enterprise is the formation of a sustainable development strategy that consists of identifying five metrics for identifying the enterprise core business: product, intangible strategic assets, consumers, distribution channels, and capital.

\section{RESEARCH OBJECTIVE, METHODOLOGY AND DATA:}

The Analytical Hierarchy Process (AHP) was developed by American professor Saati (1977). It provides a system of simple and reasonable rules for the solution of multi-criteria tasks that contain both qualitative and quantitative factors, while the quantitative factors may have different dimensions (Saati, 1977). AHP is used to solve weakly structured and unstructured problems.

Therefore, the method is used by decomposing the problem into all simple components of the part and the subsequent pairwise comparison of the components at each subsequent level of the hierarchy (Kini \& Ralfa, 1981). As a result, the relative degree of interaction of elements in the hierarchy can be expressed. The judgments could be expressed numerically. The method includes procedures for synthesizing multiple judgments, obtaining prioritization of criteria, and finding alternative solutions.

At the first stage, the most important elements of the problem are identified, then, the best way of checking observations and evaluating the elements is found. The next step may be to develop a way to apply a solution and evaluate its quality.

The hierarchy is constructed from the top (entirely from the control point of view), through the intermediate levels (the criteria on which the next levels depend) to the lowest level, which is usually the list of alternatives. The hierarchy is considered complete if each element of a given level functions as a criterion for all the elements of the level below. In another case, the hierarchy is incomplete.

In AHP, the elements of the task are divided in pairs in relation to their impact on the general characteristics for them.

Stages of AHP:

1. Setting a task.

2. Construction of the hierarchy.

3. Construction of a set of matrices of pairwise equations for each of the lower levels - one matrix for each element, which adds up to the upper level.

The crucial advantage of the AHP approach among the existing methods for evaluating alternatives is its contribution to the analysis of the structured problem and the explicit expression of judgments (Golden et al., 1989). 


\section{RESULTS AND DISCUSSION:}

The key to understanding the technology role for the enterprise is recognizing its main resource of sustainable economic growth. Modern technologies are heavy, diverse objects (systems); there could be proposed many classifications for their study (Nekrasov, 2007). For the classification (Table 1), there were selected the most significant technologies that allow to estimate the technological diversity degree of the modern economy.

Technologies are developing on the basis of the past experience of mankind, which is accumulated in various ways and improves it as vital knowledge for the society. The changes of key technologies in the society are carried out through industrial revolutions that have not only technical but also social consequences. These changes of key technologies are not isolated, but accompanied by other complementary technologies. However, it reduces the product life cycle, forcing enterprises to produce goods in small quantities, increasing the proportion of research work by reducing the cost of physical labor. The evidence from the research (Bazhal et al., 2011) confirmed that new technologies, technological know-how, new products, hyper dynamic consumer behavior create new market segments, new areas of competition, stimulate "traditional" industries, transferring experience and technical results, providing new resources, creating new conditions for the society development.

Tab. 1 - Classification of technologies in economy. Source: own research

\begin{tabular}{|l|l|}
\hline Characteristics & Types of technologies \\
\hline Affiliation to the economy & $\begin{array}{l}\text { Machine-building, metallurgical, chemical, infor- } \\
\text { mational, educational, financial, transport }\end{array}$ \\
\hline Processes that determine their content & Scientific, educational, industrial, managerial \\
\hline Scope & Scientific, educational, industrial, managerial \\
\hline Level of difficulty & Simple, complex \\
\hline Dynamics of development & Progressive, modified, modernized, obsolete \\
\hline Need for resources & Capital-intensive, energy-intensive, high-tech \\
\hline Level of discretion & Axiomatic, professional, know-how \\
\hline Quality of raw material processing & Quality of raw material processing \\
\hline Assignment & Creative, driving, double meaning \\
\hline
\end{tabular}

In terms of market prospects, the enterprise technology is classified on the basis of reducing significance for the enterprise competitive advantages formation:

a) the key technology and its competitive effect is decisive; the level of mastering it determines the specific enterprise position;

b) the basic technology that dominates the production activity, but, by virtue of its distribution, does not contribute to the formation of competitive advantages;

c) emerging technology (technology of embryonic type), which is at the stage of development or the beginning of introduction. At the moment, its influence is limited, but in the future, it could be significant. 
Technological breakthrough means the enterprise technologically ahead of the industry using more advanced production methods. Correspondingly, technological gap means lagging behind sectoral technological standards and the usage of outdated technologies. By choosing one or another group of technologies, the enterprise should determine its prospects and evaluate the possibility of internal and external risks occurring (Sinyuk \& Shevyrev, 2003).

Each key technology should not only be supported by another, but also interact with complementary technologies and be compatible with them. It is important to note that the study of the major groups of technologies requires an analysis of technological trends in the environment.

The strategic management peculiarities of the enterprise is technological development are orientation on the rapid designing and development of new technological methods, the technology development regulation of logistic curve to give it a more convex form, which is conditioned by significant losses in the form of lost profit due to delay compare do to its competitors. This is achieved through a clear formulation of administrative decision-making procedures in the field of technical and technological innovations development; parallel execution of design and technological developments, etc.

In today's market conditions, the emphasis is placed on the process of adequate selected strategies forming production and organizational structures. The dynamic balance should be maintained between the strategy and the structure, with particular attention being paid to the information and personnel provision of the structural unit responsible for the developing and strategy implementation. The methodology mastering and tools of strategic management for technological development should begin with the department organization, the one forming a technology development strategy.

Considering the peculiarities of a modern innovative economy in which enterprises operate, the following requirements can be offered to the technological development strategy: purposefulness; adaptability to change; depth with the maximum amount of information; conformity of technical qualification of managerial personnel; complexity; balance and proportionality; conformity of the nature of innovative processes in the field of technological development.

As a rule, the strategy of technological development is characterized by a reorientation of the enterprise to those goals, in which the technological component becomes one with the economic ones. In today's market conditions, the operation of the enterprise strategy of technological development should include:

- analysis and evaluation of the developed technological level of production, definition of special measures for the selection of technologies capable of ensuring the competitiveness of products;

- forming a mechanism for transforming strategic decisions in the field of technology into a specific list of actions.

The meaningful strategy of technological development is determined by the development of new products, technologies for their production, the search for new opportunities for achieving high profitability. 
The review of enterprise's technological development as an object of strategic management directs to consideration of a competitive aspect considering technological factors of this system. Each enterprise uses a set of technologies that is formed during its entire existence period. In this sense, the technology characterizes the ways of using specialized knowledgeable resources in the production, therefore, is considered as one of the main variables of strategic analysis. The evolution of technology contributes to the preservation of the enterprise in a competitive environment, the development of entire industries, causing the enterprise revival or disappearance. It is also able to change strategic segmentation, eliminating the segments boundaries or changing the segmentation itself. Finally, technology could be a factor in competitive advantages, in particular, by helping to reduce costs or enhance differentiation by modifying key business success directions.

Multifaceted and informative search of literary sources has allowed highlighting the strategic directions of the industry's technological development due to the trends interaction, some innovative economy key characteristics and their impact on the technological development of machinetool industry in general:

1. Globalization of scientific and technological relations is determined by the direction of machine-tool technologies development.

2. A change in competition basis is due to an innovative direction of technological development. New technologies ensure the labor productivity growth, saving material, fuel and energy resources, reducing the products cost, accelerating the transfer of information process. They allow producing high-quality products that leads to an increase in the market share.

3. Strategic directions of machine-tool enterprise's technological development depend on the type of state participation in this industry functioning.

4. Necessity of ensuring an appropriate level of production flexibility in the conditions of an innovative economy designing the technology development strategy.

5. Appearance and spread of new technologies and materials that ensuring the labor productivity growth, reduce costs, increase the quality and competitiveness of products, save material, fuel and energy costs.

6. Growth of new types of products and technological processes due to an increased interconnection of technologies.

7. Products life cycle reduction and pace accelerating of technology moral aging leads to abrupt product upgrades.

8. Growth of the R \& D value and uncertainty degree.

9. Requirements strengthening for the products quality and employee qualifications.

10. Importance of environmental development factors.

Nowadays, "ecological challenge" requires the development and tools implementation that aimed at the rational usage of natural resources and environmental protection. In the well-known attempts of management science to mark out the business foundations, which will provide a longterm financial and market success to the enterprise, there were different interpretations of such 
foundation. For instance, G. Hamel and K. Prahalad consider that the enterprise's core business are their key competences, the combination and recombination of which allows the enterprise to create new products and develop new markets, thereby ensuring sustainable development (Prahalad \& Hamel, 1990). Modern provisions of the enterprise resource-knowledge theory relate the enterprise long-term competitive advantages with capitalization of the knowledge resource, which allows enterprise to benefit from its uniqueness and innovation (Milner et al., 2006; Nonaka \& Takeuchi, 1995; Rajnoha et al., 2016). Common trait of these approaches is the authors' conviction that the value creation and cost is obliged to be on a certain basis - whether knowledge or dynamic capabilities, or the combination of diverse advantages - which in any circumstances cannot be lost. In other words, the central concept idea of business foundation refers to the general development management principle - preservation of the enterprise's integrity as a system.

Using the idea of focusing on the core business can be the basis of the enterprise's strategic management development, which aims to ensure sustainable economic growth through the effective use of available resources and opportunities. In our opinion, in the conditions of an innovative economy and a fluid environment, technology in the broad sense is a significant link in the formation of the core business. Under the core business, these should be understood a set of activities aspects, in which the enterprise manages to gain sustainable competitive advantages. Otherwise, it is a set of products, capabilities, customers, distribution channels and geographic factors that determine what the enterprise is or what it will become to achieve its own sustainable development and economic growth. By defining the core business, the enterprise should focus on the sustainable competitive advantages sources that make up a profitable growth platform. The purpose of strategic management is formation of a sustainable development strategy, which is to determine the business core and appropriate direction of resources for its strengthening and effective use.

However, in the context of our study, it is important to consider the technological component of the core business. At the heart of each possible competitive advantage that is discussed in Table 2 , there is a certain technology of their creation.

Tab. 2 - Interpretation of general development theory provisions by the core business concept. Source: own research

\begin{tabular}{|l|l|}
\hline $\begin{array}{l}\text { Position of general scientific theory of devel- } \\
\text { opment }\end{array}$ & $\begin{array}{l}\text { Interpretation of provisions by the core busi- } \\
\text { ness concept }\end{array}$ \\
\hline Principle of system integrity & $\begin{array}{l}\text { The core business defines the company as } \\
\text { a holistic economic system, its foundation, } \\
\text { which provides sustainable development }\end{array}$ \\
\hline Principle of system deductibility & $\begin{array}{l}\text { Determining the core business boundaries } \\
\text { allows you to avoid the risk of making a } \\
\text { strategic mistake in resource allocation and to } \\
\text { prevent the blurring of business boundaries } \\
\text { and the loss of a key management object }\end{array}$ \\
\hline
\end{tabular}




\begin{tabular}{|l|l|}
\hline Qualitative changes (improvements) & $\begin{array}{l}\text { Strengthening, expanding or modifying the } \\
\text { core business in accordance with the condi- } \\
\text { tions of internal and external environment of } \\
\text { the enterprise }\end{array}$ \\
\hline Indicators of development & $\begin{array}{l}\text { Indicators of economic growth: } \\
-\quad \begin{array}{l}\text { growth of the company's share on the } \\
\text { core business market; }\end{array} \\
\text { growth of the business income and prof- } \\
\text { itability at the same time (a growth rate } \\
\text { higher than 5.5\% per year); } \\
\text { total income of investors higher than the } \\
\text { value of capital }\end{array}$ \\
\hline Results of development & $\begin{array}{l}\text { Sustainable economic growth and mainte- } \\
\text { nance of long-term competitive advantages }\end{array}$ \\
\hline
\end{tabular}

According to the formulated principles, the strategic aspect in the enterprise's technological development management is an inclusion in the strategic process within the procedure focused on creating a technological strategy, which stipulates the co-ordination of the enterprise's common strategy with the prospect of technological innovation, aimed at forming the technological basis of today's and future competitive advantages. On that basis, we formalize our understanding of the key strategic management principles of the enterprise's technological development, the content of which is detailed in Figure 1.

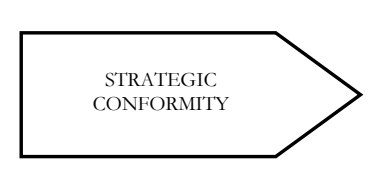

inclusion in the strategic process of the technology development strategy designing as a prospect of technological innovation and coordination of general and technological development goals of enterprise

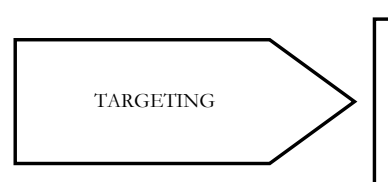

technology development strategy aims to create a technological basis for sustainable competitive advantage

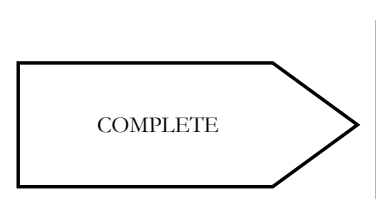

strategic chain: compliance the enterprise strategic goals with technological development goals - strategic analysis of the technological environment in the present and future time horizons the prospect of technological innovation - realization and control

Fig. 1 - Strategic management principles of an enterprise's technological development. Source: own research 
According to the formulated principles, the strategic aspect in an enterprise's technological development management is an implementation of a technological development procedure in the strategic process, i.e. one which stipulates the co-ordination of a general enterprise strategy with the prospect of technological innovation forming the basis for present and future competitive advantages.

In accordance with the definition of the basic strategic management principles of technological development along with the idea of focusing on the core business, we suggest identifying five components (F1, F2, F3, F4, F5) of a core business and a set of metrics for analysis. We introduce the necessary symbols for the mathematical representation of the methodology in Table 3.

Tab. 3 - Explication of the business core symbols. Source: own research

\begin{tabular}{|c|c|c|}
\hline $\begin{array}{l}\text { Metrics for determin- } \\
\text { ing the core business }\end{array}$ & Technologies that determine the core business & $\begin{array}{l}\text { Symbols of } \\
\text { technology }\end{array}$ \\
\hline \multirow{3}{*}{ Product $(\mathrm{F} 1)$} & 1.1. Production technology & F1(1) \\
\hline & 1.2. Innovative production technologies & $\mathrm{F} 1(2)$ \\
\hline & 1.3. Production cost optimization technologies & $\mathrm{F} 1(3)$ \\
\hline \multirow{3}{*}{$\begin{array}{l}\text { Intangible strategic } \\
\text { assets (abilities) (F2) }\end{array}$} & 2.1. Technologies of knowledge management & $\mathrm{F} 2(1)$ \\
\hline & 2.2. Technologies for making managerial decisions & $\mathrm{F} 2(2)$ \\
\hline & 2.3. Organizational technologies & $\mathrm{F} 2(3)$ \\
\hline \multirow{3}{*}{ Consumers (F3) } & 3.1. Information technology (CRN-technologies) & $\mathrm{F} 3(1)$ \\
\hline & 3.2. Marketing technologies & $\mathrm{F} 3(2)$ \\
\hline & 3.3. Service technologies & $\mathrm{F} 3(3)$ \\
\hline \multirow{4}{*}{$\begin{array}{l}\text { Distribution channels } \\
\text { (F4) }\end{array}$} & $\begin{array}{l}\text { 4.1. Sales technologies through traditional distribution } \\
\text { channels }\end{array}$ & $\mathrm{F} 4(1)$ \\
\hline & 4.2. Sales technologies through online stores & $\mathrm{F} 4(2)$ \\
\hline & 4.3. Technologies of interaction with partners & $\mathrm{F} 4(3)$ \\
\hline & 4.4. Logistics flow management & $\mathrm{F} 4(4)$ \\
\hline \multirow{2}{*}{ Capital (F5) } & 5.1. Technologies of financial management & $\mathrm{F} 5(1)$ \\
\hline & 5.2. Investment technologies & $\mathrm{F} 5(2)$ \\
\hline
\end{tabular}

The hierarchical structure of the core business model is presented in Figure 2. To construct a hierarchical model, we used the conditional symbols of the enterprise's core business metrics, as is shown in Table 3. 


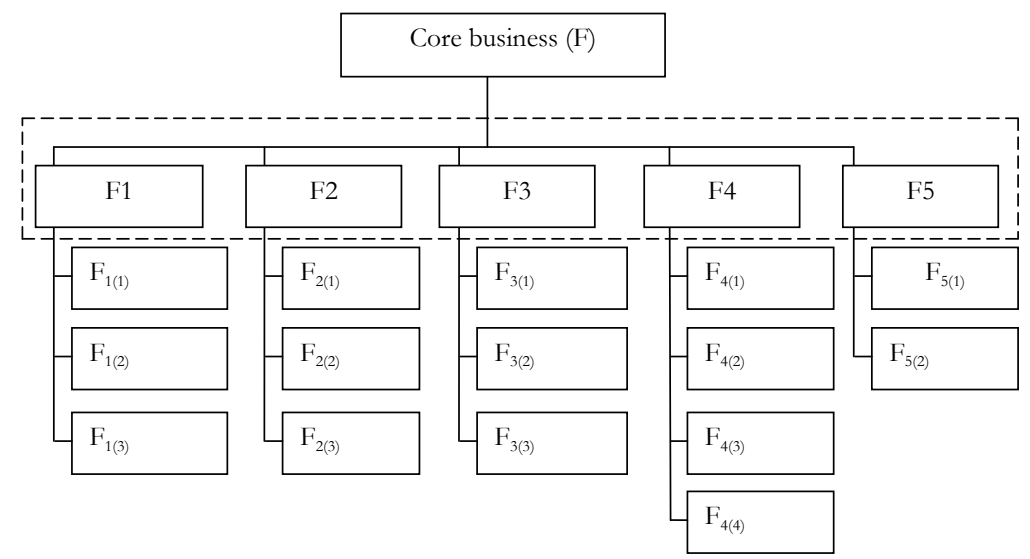

Fig. 2 - Structural representation of a machine-tool enterprise's core business. Source: own research

Legend:

F1 - product; F2 - non-material strategic assets; F3 - consumers; F4 - distribution channels; F5 - capital.

We use Fishburn's method (Emel'yanov \& Larichev, 1985) to measure the weight of the indicators in:

- the first core business subsystem:

$F_{1(2)}=F_{1(1)} \phi F_{1(3)}$, then $w_{1(2)}=w_{1(1)}=0.4, w_{1(3)}=0.2$

- the second core business subsystem:

$F_{2(1)} \phi F_{2(2)}=F_{2(3)}$, then $w_{3(1)}=0.5, w_{3(2)}=0.25, w_{3(3)}=0.25$

- the third core business subsystem:

$F_{3(3)} \phi F_{3(2)} \phi F_{3(1)}$, then $w_{3(1)}=0.166, w_{3(2)}=0.334, w_{3(3)}=0.5$

- the fourth core business subsystem:

$F_{4(1)} \phi F_{4(2)} \phi F_{4(4)} \phi F_{4(3)}$, then $w_{4(1)}=0.4, w_{4(2)}=0.3, w_{4(3)}=0.1, w_{4(4)}=0.2$

- the fifth core business subsystem:

$F_{5(1)} \phi F_{5(2)}$, then $w_{5(1)}=0.666$ i $w_{5(2)}=0.334$.

In our view, each of the subsystems has the same value in the methodology for assessing the core business, and therefore, they are characterized by the same importance of weight.

$w_{1}=w_{2}=w_{3}=w_{4}=w_{5}=1 / 5=0.2$ or $20 \%$

For subjective pairwise comparisons, we used the scale of relative importance of the elements in relation to the general objective (Saati, 1977). For a group of matrices of even pairwise relations, sets of local priorities are formed which express their relative influence on elements of a higher level (Larichev \& Moshkovich, 1996). From here we obtained a two-level hierarchical system for a comprehensive assessment of the enterprise's core potential of any activity. 
We normalized the system in order to estimate the priority vector using the formula (1):

$$
\begin{aligned}
& F=w_{1} F_{1}+w_{2} F_{2}+w_{3} F_{3}+w_{4} F_{4}+w_{5} F_{5}=0.2 F_{1}+0.2 F_{2}+0.2 F_{3}+0.2 F_{4}+0.2 F_{5} \\
& \text { if } \\
& F_{1}=0.4 F_{1(1)}+0.4 F_{1(2)}+0.2 F_{1(3)} \\
& F_{2}=0.5 F_{2(1)}+0.8 F_{2(2)}+0.8 F_{2(3)} \\
& F_{3}=0.166 F_{3(1)}+0.334 F_{3(2)}+0.5 F_{3(3)} \\
& F_{4}=0.4 F_{4(1)}+0.3 F_{4(2)}+0.1 F_{4(3)}+0.2 F_{4(3)} \\
& F_{5}=0.666 F_{5(1)}+0.334 F_{5(2)}
\end{aligned}
$$

It should be noted that a possible construction of a multiplicative hierarchical two-level system is possible:

$$
\begin{aligned}
& F_{1(2)}=F_{1}^{0.2} \times F_{2}^{0.2} \times F_{3}^{0.2} \times F_{4}^{0.2} \times F_{5}^{0.2} \\
& \text { if } \\
& F_{1}=F^{0.4}{ }_{1(1)} \times F^{0.4}{ }_{1(2)} \times F_{1(3)}^{0.2} \\
& F_{2}=F^{0.5}{ }_{2(1)} \times F^{0.8}{ }_{2(2)} \times F^{0.8}{ }_{2(3)}^{0.5} \\
& F_{3}=F^{0.166}{ }_{3(1)} \times F^{0.334}{ }_{3(2)} \times F^{3(3)} \\
& F_{4}=F_{4(1)}^{0.4} \times F^{0.3(2)} \times F_{4(3)} \times F^{0.2}{ }_{4(3)} \\
& F_{5}=F^{0.666}{ }_{5(1)}^{0.334}{ }_{5(2)}
\end{aligned}
$$

It should also be noted that the developed model is universal and allows the assessment of the potential core as a separate machine-tool enterprise, as well as the groups of enterprises engaged in these activities or different ones. For a more precise analysis of the enterprise's technological development (besides the given model), we draw attention to the decomposition of the enterprise's technological structure in three interconnected outlines: a core business outline, periphery outline and perspective outline, as is shown in Figure 3. The basis of distinguishing of these three contours is the spatio-temporal criterion of the technology's relation to competitive advantages and economic growth sources. The result of the decomposition of the enterprise's technological structure is the identification of the technological basis for its potential competitive advantages.

From the strategic management point of view, a technological structure analysis of the enterprise should be included featuring not only technologies within a current time horizon, but also those technologies which might influence the functioning of the enterprise and its competitive position in the future. Moreover, this technology assessment of success and effectiveness depends on the prediction of the exact circumstances regarding the emergence of the future technologies that can significantly affect business development. According to Figure 3, the business core consists of production, management, information, organizational technologies through which the enterprise creates a corresponding complex of diverse competitive advantages.

Considering business core technologies in the context of competitive advantages, it would be logical to predict that their main qualitative characteristics should be uniqueness and copy pro- 
tection. However, it is known that technology itself does not exhaust the possibilities for securing competitive advantages, but only creates the technical foundation for progress. Within the structure of a certain aspect of strategic competitive advantage, the decisive role is not played only by technology, but also by a mobile combination of technology and strategic thinking focused on forming or enlarging the competitive margin of the enterprise.

Nevertheless, it has also been established (Saati, 1977; Larichev, 1979) that this approach is effective and promising in terms of identifying a business core, since it: 1) accelerates significantly the accounting and process of analysis as well as evaluation of the use of resources such as labor, material, financial and energy resources; 2) improves the quality of operational control of production activities. In the framework of maintaining the enterprise's competitiveness, this facilitates the evaluation of the specifics of its activities, especially in conditions of uncertainty, to determine the optimal technological methods of production.

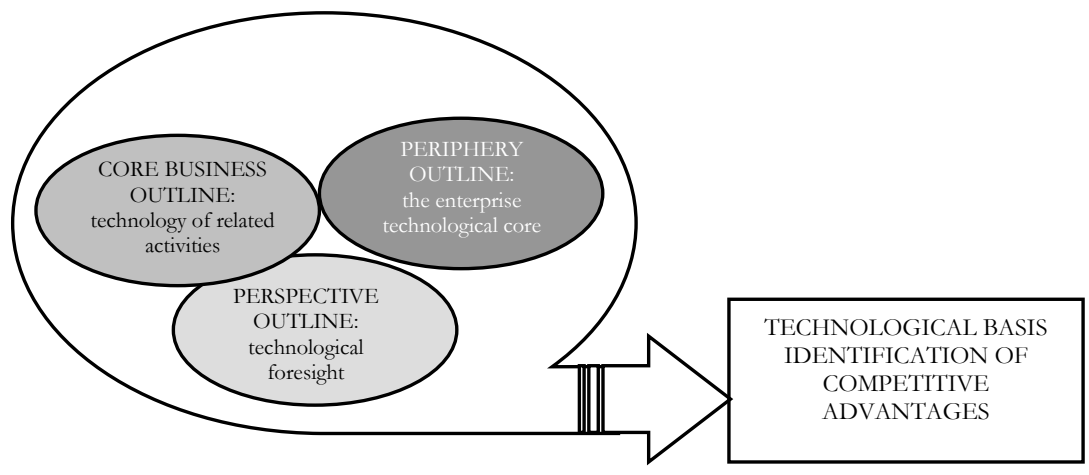

Fig. 3 - Schematic description of the enterprise's technological structure decomposition. Source: own research

Therefore, the possibility of using technology as a basis for the formation and enhancement of sustainable competitive advantages is associated with the strategic context of technological development management. The strategic management of technological development should be carried out in accordance with certain principles that will ensure the consistency of the enterprise's strategic goals and the content of its technological choices (Malinetsky, 2013):

1. Principle of branch technological imperative.

2. Principle of strategic tasks priority of company development.

3. Principle of enterprise corporate and technological strategy correlation as a whole and a part.

4. Principle of resource realism.

5. Principle of feedback: balance of technological core and embryonic technologies.

6. Principle of effectiveness. 


\section{CONCLUSION}

The strategic analysis procedures which can be formed using our developed model of technological developments acquire their own content and are supported by the usage of appropriate methodological tools. In particular, the goal of the analysis of an enterprise's external environment is to determine the competition structure in the industry and to determine target areas of industrial technology. The tool to achieve this goal is the identification of the weight of technological competition factors using the classical analysis model "The five forces of competition," along with measuring the threat of substitute technologies. The impact on competition as well as the intensity in the field of the threat of technology-substitutes were confirmed by analyzing the competition structure in the overall European machine-tool industry.

The analysis of the enterprise's internal environment was carried out to identify the technological basis for securing competitive advantages in the current and future periods. The analytical tool used was the decomposition of the enterprise's technological structure in terms of outlines of the core business, periphery and prospects, the result of which was the determination of production, marketing, management, information and other types of technologies forming the technological basis of enterprise's core business and its technological perspective for possible implementation under certain conditions of the environment. The assessment of trends as well as the forecasting of the consequences of the technology development strategy are extremely important in making decisions on the direction of enterprise development. It was shown to be expedient to carry out such an assessment with the help of AHP. Finally, as such an assessment is undertaken, all factors need to be considered in order to make reliable decisions.

Regarding further research in this direction, we can state that AHP is an efficient and effective method of solving difficult structured management tasks, one which should be used for the scientific substantiation of managerial decisions in the process of developing a technology development strategy for a modern enterprise.

\section{References}

1. Allen J., \& Zook, C. (2001). Profit from the core: a return to growth in turbulent times. Harvard Business School Press: Bain \& company, Inc.

2. Bazhal, Y., Fedulova, L., \& Osetsky, V. (2011). The technological imperative of the strategy of socioeconomic development of Ukraine. Kyiv: National Academy of Sciences of Ukraine.

3. Bilan, Y., Mishchuk, H., \& Pylypchuk, R. (2017). Towards sustainable economic development via social entrepreneurship. Journal of Security \& Sustainability Issues, 6 (4), $16-245$.

4. Byun, J., Sung, T. E., \& Park, H. W. (2018) Technological innovation strategy: how do technology life cycles change by technological area. Technology Analysis \& Strategic Management, 30 (1), 98-112, https://doi.org/10.1080/09537325.2017.1297397

5. Draskovic, M., Milica, D., Mladen, I., \& Chigisheva, O. (2017). Preference of institutional changes in social and economic development. Journal of International Studies, 10 (2), 318-328. https:// doi.org/10.14254/2071-8330.2017/10-2/22 
6. Emel'yanov, S. V., \& Larichev, O. I. (1985). Mnogokriterial'nye metody prinyatiya resheniy Multi criteria decision making methods. Moskow: Znanie, 32.

7. Del Prado F. L., \& Rosellon M. A. (2017). Developing technological capability through human resource management: case study from the Philippines. Asian Journal of Technology Innovation, 25 (2), 310-32. https://doi.org/10.1080/19761597.2017.1385973

8. Golden B. L., Wasil E., \& Harker P. (1989). The analytic hierarchy process: applications and studies. New York: Springer-Verlag.

9. Kačerauskas, T. (2015). Technologies in creative economy and creative society. Technological and Economic Development of Economy, 21 (6), 855-868. https://doi.org/10.3846/20294913.201 5.1036325

10. Kini, R. L., \& Ralfa, K. (1981). Prinyatie resheniy pri mnogikh kriteriyakh predpochteniya $i$ zamescheniya, Making decisions with a lot of criteria of preference and substitution. Moskow: Radio i svyaz'.

11. Krayneva, R., Bugaev, A., Zhuravleva, T., \& Vojtovič, S. (2017). Management and promotion of economic innovation potential. Journal of International Studies, 10 (1), 146-158. https://doi.org/10.14254/2071-8330.2017/10-1/10

12. Larichev, O. I. (1979). Nauka i iskusstvo prinyatiya resheniy. Skill and science of decision making. Moskow: Nauka.

13. Larichev, O. I. (1987). Ob'ektivnye modeli i sub'ektivnye resheniya. Objective model and the subjective decisions. Moskow: Nauka.

14. Larichev, O. I., \& Moshkovich, E.M. (1996). Kachestvennye metody prinyatiya resheniy. Verbal'ny analiz resheniy. Qualitative methods of decision making. Verbal decisions analysis. Moskow: Nauka, Fizmatlit.

15. Lim, G. (2016) Managing Technological Development: A Study of Vietnam's Telecommunication Goods Industry. Journal of Comparative Asian Development, 15 (2), 276-299. https://doi.org/10.1080/15339114.2016.1227272

16. Malinetsky, G.G. (2013). Prinzipy prognozirovaniia tehnologicheskogo razvitiia [Principles of forecasting technological development]. Retrieved from: http://spkurdyumov.narod.ru/ PrProgObRaz.htm

17. Milner, B.Z., Rumyantseva Z.P., Smirnov V.G., \& Blinnikova A.V. (2006). Upravlenie znaniiami v korporaziizah Knowledge management in corporations. Moskau: Delo.

18. Nekrasov, A. (2007). Osnovy tehnologicheskogo menedgementa. Fundamentals of Technological Management. Moskau.: MADI (GTU).

19. Nonaka, I., \& Takeuchi, H. (1995). The knowledge creating company: how Japanese companies create the dynamics of innovation. New York: Oxford University Press.

20. Prahalad, C., \& Hamel, G. (1990). The core competence of the corporation. Harvard Business Review, 68 (3), 79-91. 
21. Rajnoha, R., Lesníková, P., \& Korauš, A. (2016), From Financial Measures to Strategic Performance Measurement System and Corporate Sustainability: Empirical Evidence from Slovakia. Economics and Sociology, 9 (4), 134-152. https://doi.org/10.14254/2071789X.2016/9-4/8

22. Saati, T.L. (1977). Matematicheskie modeli konfliktnykh situatsiy [Mathematical models of conflict situations]. Moskow: Sovetskoe radio.

23. Schumpeter, J. (2011). Theory of Economic Development: An Inquiry into Profits, Capital, Credit, Interest, and the Business Cycle. Kyiv: Publishing House of "Kyiv-Mohyla Academy".

24. Sinyuk, V. G., \& Shevyrev A. V. (2003). Ispol'zovanie informatsionno-analiticheskikh tekhnologiy pri prinyatii upravlencheskikh resheniy. Use of information and analytical technologies in management decisions. Moskow: Ekzamen.

25. Suder, A., \& Kahraman, C. (2016). Multicriteria analysis of technological innovation investments using fuzzy sets. Technological and Economic Development of Economy, 22 (2), 235-253. https://doi.org/10.3846/20294913.2014.994191

26. Szilágyi, G. A. (2017). Exploration Knowledge Sharing Networks Using Social Network Analysis Methods. Economics and Sociology, 10 (3), 179-191. https://doi.org/10.14254/2071789X.2017/10-3/13

27. Tsai, K. H., \& Wang, J. C. (2008). External technology acquisition and firm performance: A longitudinal study. Journal of Business Venturing, 23 (1), 91-112. https://doi.org/10.1016/j. jbusvent.2005.07.002

28. Tsai, K. H., \& Wang, J. C. (2009). External technology sourcing and innovation performance in LMT sectors: An analysis based on the Taiwanese Technological Innovation Survey. Research Policy, 38 (3), 518-26. https://doi.org/10.1016/j. respol.2008.10.007

29. Werther, W. B., Berman, E., \& Vasconiellos, E. (1994). The future of technology management. Organisational Dynamics, 22 (3), 20-32.

30. Zemlickiené, V., Mačiulis, A., \& Tvaronavičienė, M. (2017). Factors impacting the commercial potential of technologies: expert approach. Technological and Economic Development of Economy, 23 (2), 410-427. https://doi.org/10.3846/20294913.2016.1271061

\section{Contact information}

Assoc. prof. Alla S. Ivanova, Ph.D.

Odessa State Agrarian University, Ukraine

Department of Management

Ukraine

E-mail:allaserg.ivanova@gmail.com

ORCID: 0000-0002-0641-6408

Assoc. prof. Nataliia G. Holionko, Ph.D.

Kiev National Economic University named after Vadim Hetman, Ukraine

Department of Management

E-mail:nataliia.holionko@kneu.ua

ORCID: 0000-0003-3755-1562 
Assoc. prof. Tetiana B. Tverdushkea, Ph.D.

International Institute of Business (IIB), Ukraine

Department of Business Administration

Ukraine

E-mail: t.b.tverdushka@gmail.com

ORCID: 0000-0002-0647-4309

ssoc. prof. Tadeusz. Olejarz, Ph.D.

Rzeszow University of Technology Rzeszow, Poland

Faculty of Management

Poland

E-mail:olejarz@prz.edu.pl

ORCID: 0000-0001-7940-3248

Prof. Alina Y. Yakymchuk, Ph.D.

National University of Water and Environmental Engineering, Ukraine

Public Administration, Documentation and Information Activities Department

Ukraine

E-mail:alinayakim@ukr.net

ORCID: 0000-0002-5038-5215 